\author{
Burdo 0., Bezbakh I., \\ Shyshov 5., Zykov A., \\ Gavrilov A., Vsevolodov 0., \\ Sirotyuk I., Terziev 5.
}

\title{
EXPERIMENTAL STUDIES OF THE KINETICS OF INFRARED DRYING OF SPENT COFFEE GROUNDS
}

Об’єктом дослідження є прочес сушіння кавового шламу. В умовах сучасного виробництва гостро ставляться питання раціонального використання енергї в усіх процесах харчової технологї, включаючи сушіння. У багатьох харчових технологіях використовується в 2-3 рази більше енергї, ніж їі фізично необхідно на прочес. Цим визначається енергоємність виробництва і якість продуктів. Процеси сушіння відносяться до найбільш енергоємних, і в багатьох випадках частка енергї в собівартості продукції складає до 30 \%. При сушінні кавового шламу використовують в основному конвективні сушарки, енерговитрати яких становлять 5 МДж/кг видаленої вологи і вище. На випаровування вологи при конвективному сушінні витрачається 40 \% підведеної енергіі. Також значним недоліком конвективних сушарок є викид відпрацьованого теплоносія в атмосферу, який має тепловміст всього лише на 10-15\% менше, ніж гаряче повітря, що подається в сушильну камеру. В роботі пропонується використання інфрачервоного випромінювання для сушіння кавового шламу в установках періодичної та безперервної діі. Це дозволить в перспективі знизити питомі енерговитрати. В ході дослідження визначено вплив інтенсивності енергетичного підведення, температури, швидкості потоку повітря, товщини шару продукту і питомого навантаження на кінетику періодичної інфрачервоного сушіння кавового шламу. Визначено вплив інтенсивності енергетичного підведення, питомого навантаження, швидкості стрічки, кількості інфрачервоних модулів на кінетику безперервного інфрачервоного сушіння кавового шламу. Проведено порівняння результатів з конвективним сушінням за параметрами питомого енергоспоживання. Особливістю застосування інфрачервоного випромінювання є більша ефективність і висока швидкість видалення вологи з поверхневих шарів кавового шламу, i як наслідок, збільшення продуктивності способу сушіння, зниження питомих енерговитрат. Отримані в ході роботи питомі енерговитрати при інфрачервоному сушінні кавового шламу склали 3,2 МДж/кг. Це нижче існуючих конвективних сушарок.

Ключові слова: інфрачервоне сушіння, кавовий шлам, кінетика сушіння, установки періодичної та безперервної дї, питомі енерговитрати.

\section{Introduction}

Recently, the technique of dehydration of products and materials is significantly ahead of the theoretical positions of drying [1]. Not only the classical literature on drying problems [2], but also the special literature [3, 4] do not give specific recommendations on the design of combined drying principles, units with electromagnetic energy supply. At the same time, precisely such units are actively progressing and are characterized by serious problems in modeling. Therefore, while the only reliable way of their research is an experiment.

Spent coffee grounds are considered one of the most common biological resources in the world for use as green energy. Biodiesel, bioethanol, bio-oil and fuel pellets are biofuels derived from these wastes [5]. To get them, spent coffee grounds must be dried due to the high moisture content.

Also, the grounds have high potential due to its beneficial properties for health, however, due to the high water content, it is necessary to stabilize it without affecting the bioactive properties.

In modern production, the issues of rational use of energy in all processes of food technology, including drying, are urgently raised. In many food technologies, 2-3 times more energy is used than is physically necessary for the process. This determines the energy intensity of production and the quality of products. Therefore, it is relevant to study the drying process of spent coffee grounds, the use of new drying methods that will reduce energy costs.

\section{The object of research and its technological audit}

The object of research is drying of spent coffee grounds. Drying processes are among the most energy-intensive, and in many cases the proportion of energy in the cost of production is up to $30 \%$. When drying of spent coffee grounds, convective dryers are mainly used, the energy consumption of which is $5 \mathrm{MJ} / \mathrm{kg}$ of removed moisture and above. Convective drying uses $40 \%$ of the supplied energy to evaporate moisture. Also, a significant drawback of convective dryers is the discharge of waste coolant into the atmosphere, which has a heat content of only 10-15\% less than the hot air supplied to the drying chamber. 


\section{The aim and objectives of research}

The aim of research is conducting experimental studies of the kinetics of infrared drying (IR) of spent coffee grounds.

To achieve this aim it is necessary to perform the following objectives:

1. To determine the influence of regime parameters (intensity of energy supply, temperature, air flow rate, product layer thickness and specific load) on the kinetics of periodic IR drying of spent coffee grounds.

2. To determine the influence of regime parameters (intensity of energy supply, specific load, tape speed, number of IR modules) on the kinetics of continuous IR drying of spent coffee grounds.

\section{Research of existing solutions of the problem}

Drying in most cases is an energy-intensive process, which usually leads to noticeable changes in the quality characteristics of the product due to the long drying time at high temperatures. The drying process of food materials is extremely complex, including the conjugate transitional mechanisms of heat, mass, and momentum transfer, accompanied by physical, chemical, and phase transformations [6-8].

For drying of spent coffee grounds, different methods are used - convective, microwave, infrared (IR), contact. They have their advantages and disadvantages.

The work [9] analyzes the kinetics of drying of spent coffee grounds in a convective dryer at various temperatures: $100,150,200$, and $250{ }^{\circ} \mathrm{C}$, and sample thickness: $5,10,15$, and $20 \mathrm{~mm}$. As a result, the drying curves are compared with the basic mathematical models for drying agricultural products. Effective moisture diffusion coefficients are obtained in the range between $1.29 \cdot 10^{-9}$ to $28.8 \cdot 10^{-9} \mathrm{~m}^{2} / \mathrm{s}$. It is shown that the drying rate is quite high, but the specific energy consumption for the process is not calculated and the task is not to study IR drying for grounds. Studies $[10,11]$ show that the specific energy consumption for the convective drying process is from $5 \mathrm{MJ} / \mathrm{kg}$ to $9 \mathrm{MJ} / \mathrm{kg}$ and the discharge of waste coolant into the atmosphere.

As part of the study [12], a shelf dryer with an air compressor is developed for drying of spent coffee grounds. The use of a compressor allows the use of free waste heat for drying. A model has been developed to take into account the influence of the maximum number of installed pallets and layer thickness on the dryer capacity. An experimental determination of the drying time for coffee grounds with different thicknesses showed that each centimeter of increase in layer thickness increased the drying time by 3 times. The dryer performs 6 cycles during normal cafe hours (12 hours) and daily productivity of the dryer is $5400 \mathrm{~g}$. However, it remains unknown to use the dryer for a production scale, with an average plant grounds amount of about 2 tons per shift [13].

In [14], microwave drying of spent coffee grounds briquette in combination with mineral additives is studied at various input powers $(119-700 \mathrm{~W})$. As additives, $10 \%$ sodium chloride, $10 \%$ sodium sulfate and $10 \%$ lignite are used. Compared with untreated briquette, the required drying time of the briquette with the addition of $\mathrm{Na}_{2} \mathrm{SO}_{4}$ and $\mathrm{NaCl}$ at $385 \mathrm{~W}$ decreases by $38 \%$ and $18 \%$.
Accordingly, while the drying time increased by $9 \%$ with the addition of fine lignite. The authors do not consider the possibility of IR drying in a thin layer.

In [15], the main goal is to evaluate the effect of various convective drying conditions on some technological and functional properties of the spent coffee grounds and to determine the kinetics of thermal decomposition of chlorogenic acids. The experiments are carried out at an air temperature of $40-60{ }^{\circ} \mathrm{C}$, an air flow rate of $1.0-2.0 \mathrm{~m} / \mathrm{s}$ and a layer thickness of $0.01-0.2 \mathrm{~m}$. The effective diffusion coefficient, humidity, water activity, and water retention capacity, oil, antioxidant ability are determined. In general, it is concluded that the convective drying process is an acceptable method of processing spent coffee grounds, since it allows to save antioxidant compounds that are potentially healthy, providing a stable low moisture content that can be used in food products. However, in this work, the possibility of periodic and continuous IR drying in a thin layer is not considered.

In [16], research is carried out on the drying regimes by infrared radiation of four typical biomass briquettes (poplar leaves, cotton stalk, spent coffee grounds and eucalyptus bark). The effect of the temperature of the radiation source $\left(100-200{ }^{\circ} \mathrm{C}\right)$ on the heat transfer of the samples is considered. With an increase in temperature from 100 to $200{ }^{\circ} \mathrm{C}$, the time required for drying four biomass briquettes decreases by approximately $59-66 \%$, and the specific energy consumption is $2.2-3.5 \mathrm{MJ} / \mathrm{kg}$. The experiments are carried out on briquettes, although the use of infrared drying in a thin layer should give a greater effect, since the radiation will more effectively penetrate the product.

An analysis of the literature data shows that the chosen direction of experimental studies is promising and is determined by the need to study the kinetics of mass transfer during the drying of spent coffee grounds in plants with IR energy generators. It is planned to conduct experimental studies of periodic and continuous dehydration processes in the infrared field.

\section{Methods of research}

Studies in a fixed bed of the product are carried out on an experimental stand (Fig. 1). The stand consists of an IR camera (1), an electronic balance (2), two IR generators (3), a product cartridge (4), a system for measuring the temperature of the product and the air in the chamber (5) and energy costs $(7,8)$.

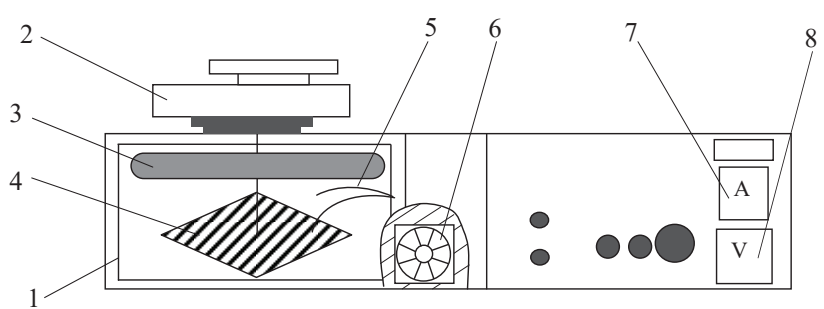

Fig. 1. Scheme of a laboratory stand for studying the process of infrared (IR) drying in a fixed layer: 1 - IR camera; 2 - electronic scales; 3 - IR generator; 4 - cartridge with a product; 5 - system for measuring the temperature of the product and air in the chamber; 6 - fan; 7 - ammeter; 8 - voltmeter

The movement of air in the chamber is provided by a fan (6). The cassette is square in shape with sides $200 \mathrm{~mm}$ 
and sides $10 \mathrm{~mm}$ high for the product is made of metal mesh. The cassette is suspended from the scales by a system of metal cables, the length of which is regulated, which makes it possible to set the required product distance from the emitters within $7-15 \mathrm{~cm}$.

$550 \mathrm{~W}$ quartz short-wave light elements act as generators of IR radiation, which provide an exit to the temperature regime in almost 30 seconds. The supply voltage is regulated by a system consisting of a laboratory transformer, an ammeter of accuracy class 2.5 and a voltmeter of accuracy class 1.5. According to the testimony of the ammeter and voltmeter, the power consumption is determined.

The air speed at the outlet of the chamber is measured with an electronic anemometer, Testo 410-2 thermohygrometer (China). Air speed varies between $0.5-2.5 \mathrm{~m} / \mathrm{s}$ by adjusting the speed of the fan motor using a laboratory autotransformer (LATR). The system for measuring the temperature of the product and the air in the chamber consists of two chromel-copel thermocouples shielded from the action of infrared radiation with an asbestos cord and aluminum foil, and a digital micro-voltmeter RT-0193 (China) with an ambient temperature compensator.

The experimental part of the research includes a series of experiments with different loads (product weight) and different radiation powers supplied to the chamber. The results of measuring the weight and temperature of the layer are recorded by the hardware-software complex of the stand (Fig. 2).

Electronic scales record the change in mass of the product. By reducing the mass, the amount of removed moisture is determined. Preliminarily, standard methods of drying to a constant weight determine the initial moisture content of the grounds and the mass of dry matter $\left(m_{D M}\right)$, which remains constant in the grounds. Thus, the current moisture content of the grounds $\left(W_{i}\right)$ is determined by the value of the current mass $\left(m_{i}\right)$ according to the formula:

$$
W_{i}=\frac{m_{i}-m_{D M}}{m_{i}}
$$

Spent coffee grounds are used as a raw material. The product is placed in a dense layer on the suspension of the balance in the center of the chamber. In continuous mode, the computer processed the information that came from the balance and from thermocouples. The monitor displayed lines of trends in the mass of the product, the drying line and the drying speed of the product, product temperature, air in the chamber, dry and wet thermometers at the air outlet from the chamber.

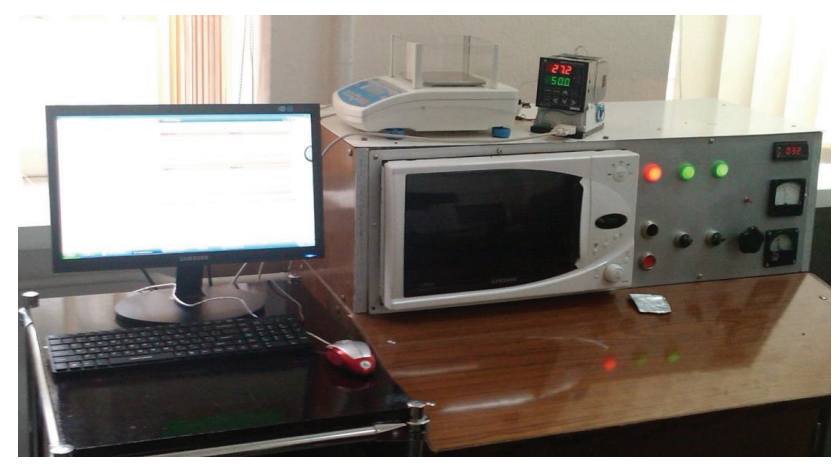

Fig. 2. A computerized stand for the study of the dehydration kinetics in an electromagnetic infrared field
Continuous dehydration is studied on a tape infrared dryer (Fig. 3). The stand consists of a loading hopper (1), a conveyor tape (2), three modules of IR processing of raw materials (3). The IR processing module includes two quartz infrared emitters with a power of $550 \mathrm{~W}$ and a resistance of $50 \mathrm{Ohms}$ each. The emitters are located at a distance of $13 \mathrm{~cm}$ from the surface of the conveyor tape, and their power is regulated by thyristor voltage regulators and is controlled by an electronic digital multimeter UT202 (China). The moisture content of the grounds is determined by drying the samples to constant weight, samples are taken before and after each IR module. The tape is driven by an Oriental Motor 6-90 W electric motor (USA), the speed of which is regulated by a potentiometer. The voltage is controlled by a TL-4M voltmeter (China).

The loading hopper is equipped with a gateway that controls the thickness of the product layer on the tape within 3-10 $\mathrm{mm}$, regardless of its speed.

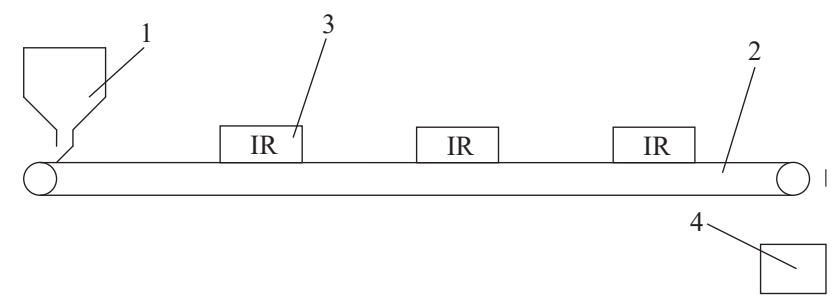

Fig. 3. An experimental stand for studying the processes of infrared (IR) drying of foud products: 1 - hopper; 2 - tape conveyor; 3 - IR emitter; 4 - finished product hopper

The range of studies is given in Table 1.

Table 1

Research range for infrared (IR) drying of spent coffee grounds

\begin{tabular}{|c|c|c|c|c|}
\hline $\begin{array}{c}\text { Raw } \\
\text { material }\end{array}$ & $\begin{array}{c}\text { IR specific } \\
\text { power }\end{array}$ & $\begin{array}{c}\text { Temperature } \\
T,{ }^{\circ} \mathrm{C}\end{array}$ & $\begin{array}{c}\text { Load, } \\
g, \mathrm{~kg} / \mathrm{m}^{2}\end{array}$ & $\begin{array}{c}\text { Processing } \\
\text { time, } \tau, \mathrm{min}\end{array}$ \\
\hline $\begin{array}{l}\text { Spent coffee } \\
\text { grounds }\end{array}$ & $2.5-10 \mathrm{~kW} / \mathrm{m}^{2}$ & $45-130^{\circ} \mathrm{C}$ & $2.5-7.5$ & $20-100$ \\
\hline
\end{tabular}

Grounds with a specific gravity of $2.5-10 \mathrm{~kg} / \mathrm{m}^{2}$ are placed in the chamber at an air speed of $0-2.5 \mathrm{~m} / \mathrm{s}$ at the outlet of the chamber.

The processing time, temperature, and grounds mass during processing are recorded. The specific load of the material $(g)$ shows the mass $(m)$ of the product per unit surface area $(F)$, and the specific power is the infrared energy that is consumed per $1 \mathrm{~m}^{2}$ of the processed surface.

\section{Research results}

6.1. Studies of drying of spent coffee grounds in the fixed layer. The effect of input power on the speed and temperature of the drying process is studied. Thermograms of the process and the change in grounds moisture over time are shown in Fig. 4, 5.

Spent coffee grounds absorb infrared light well. On thermograms (Fig. 4), a period of a slow increase in temperature is observed simultaneously with a decrease in the humidity of the product, which indicates that the energy of infrared radiation is spent on the moisture evaporation. This is consistent with the fact that water absorbs infrared radiation throughout the IR spectrum. Only in the case of 
a supply of $10 \mathrm{~kW} / \mathrm{m}^{2}$, the temperature rises quickly and almost linearly, that is, much more energy is supplied than is necessary for the moisture evaporation. And this drying mode can be considered ineffective due to inconsistency in energy consumption and the amount of product.

An increase in the power supplied to the product by 4 times reduces the drying time by 2.5 times (Fig. 5).

An important parameter of the drying process is the thickness of the product layer, which is associated with the specific loading of the product in the dryer. Infrared radiation is able to penetrate into the product to a certain depth, at the same time, moisture must pass into the environment from the lower layers of raw materials.

In this series of experiments, at a constant specific power of the emitters, the specific load of the product changes (Fig. 6).

The temperature difference of the product at all loads does not exceed $10{ }^{\circ} \mathrm{C}$, however, the greater the thickness of the layer, the lower the intensity of moisture removal (Fig. 6).

The specific load significantly affects the drying rate (Fig. 6). On the one hand, increasing the thickness of the layer increases the productivity of the unit. On the other hand, the speed of the process is reduced due to less penetration of infrared radiation into the product, as well as resistance to moisture transfer to the diffusion medium that the upper layers of the grounds create. A decrease in the thickness of the grounds layer by a factor of 2 leads to an increase in the drying rate by a factor of $2-3$. An increase in the thickness of the layer also leads to uneven heating and drying of the product. While the temperature in the thickness of the grounds does not exceed $70^{\circ} \mathrm{C}$, the surface heats up to $150{ }^{\circ} \mathrm{C}$ and above.

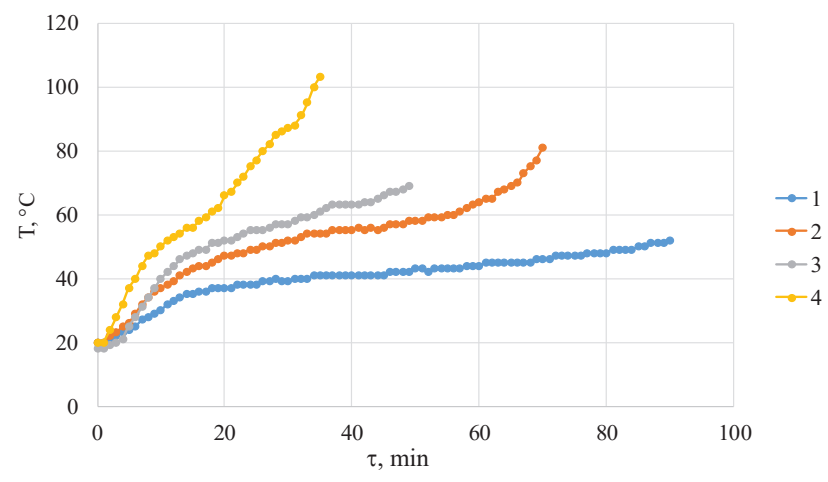

Fig. 4. Thermograms of the drying of spent coffee grounds process at a specific power: $1-2.5 \mathrm{~kW} / \mathrm{m}^{2} ; 2-5 \mathrm{~kW} / \mathrm{m}^{2} ; 3-7.5 \mathrm{~kW} / \mathrm{m}^{2}$ $4-10 \mathrm{~kW} / \mathrm{m}^{2}$

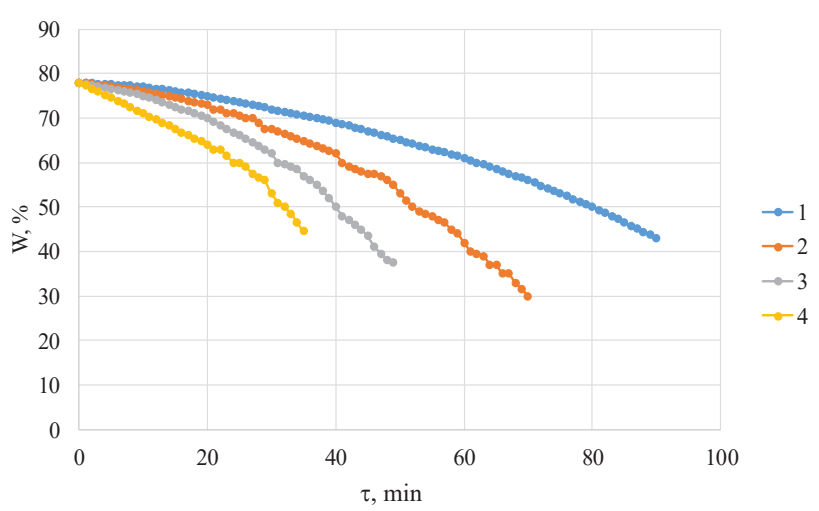

Fig. 5. Lines of change in humidity at specific power: $1-2.5 \mathrm{~kW} / \mathrm{m}^{2} ; 2-5 \mathrm{~kW} / \mathrm{m}^{2} \cdot 3-7.5 \mathrm{~kW} / \mathrm{m}^{2} \cdot 4-10 \mathrm{~kW} / \mathrm{m}^{2}$

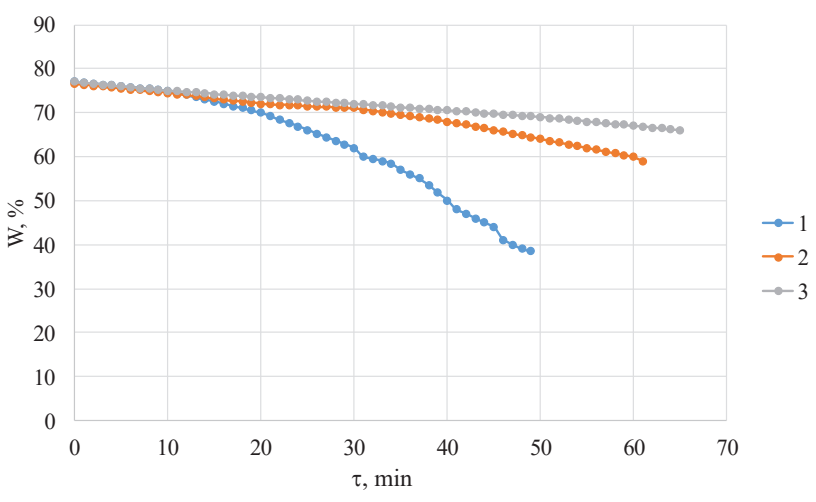

Fig. 6. Lines of change in humidity at specific power: $1-2.5 \mathrm{~kW} / \mathrm{m}^{2} ; 2-5 \mathrm{~kW} / \mathrm{m}^{2} ; 3-7.5 \mathrm{~kW} / \mathrm{m}^{2}$

The closer the raw materials are to the emitter, the less energy is dissipated and more transferred to the product. At the same time, when the grounds are close to the emitters, uneven heating can occur. The experiments are carried out with a specific load of $2.5 \mathrm{~kg} / \mathrm{m}^{2}$, the summed power is $7.5 \mathrm{~kW} / \mathrm{m}^{2}$. The distance from the product layer to the emitter changes (Fig. 7).

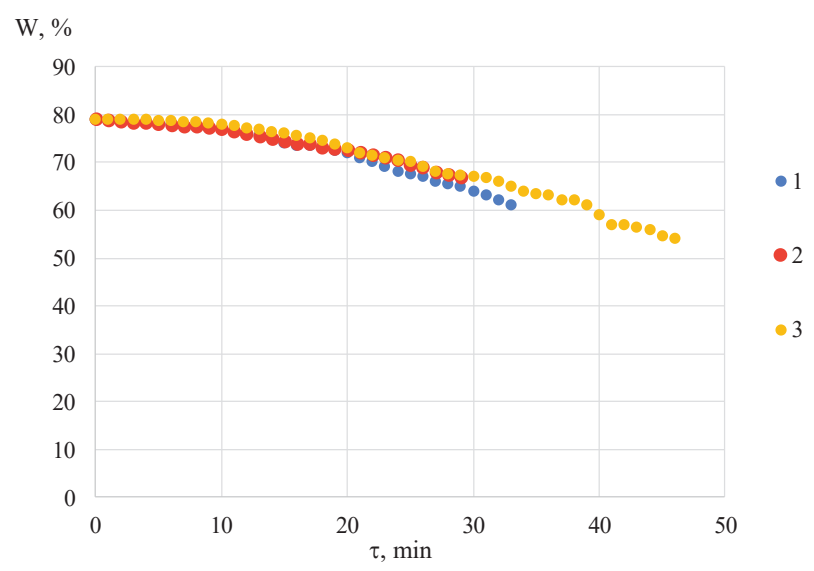

Fig. 7. Humidity change lines at a distance to emitters: $1-7 \mathrm{~cm} ; 2-10 \mathrm{~cm} ; 3-13 \mathrm{~cm}$

Changing the distance of the product from the emitter within the studied limits does not significantly affect the rate of moisture removal from the grounds (Fig. 8). The moisture difference between the experiments during the entire process does not exceed $5 \%$. At distances of 10 and $13 \mathrm{~cm}$, the difference is less than $1 \%$, that is, the drying speeds are almost the same.

On the other hand, decreasing the distance leads to a significant increase in the temperature of the grounds (Fig. 8). Under such conditions, there is a threat of thermal damage to the top layer of the raw material, which leads to a deterioration in the quality of the final product. At the same time, the lower layers of the product are not dried.

The influence of the air speed in the chamber is determined. The experiments are carried out with a specific load of $2.5 \mathrm{~kg} / \mathrm{m}^{2}$ and a supply of $5 \mathrm{~kW} / \mathrm{m}^{2}$ of power at a distance of $0.13 \mathrm{~m}$ from the emitters. Air speed varies from 0 to $2.5 \mathrm{~m} / \mathrm{s}$ (Fig. 9, 10).

Forced ventilation of the drying chamber, on the one hand, reduces the diffusion resistance of the boundary layer, reduces the concentration of moisture in the air, and thus increases the rate of moisture transfer from raw 
materials to the diffusion medium. On the other hand, thermal energy losses occur with air, which, conversely, reduces the speed and energy efficiency of the drying process. With increasing air speed in the chamber, the temperature of the product decreases (Fig. 10), which indicates an increase in energy loss with exhaust air.

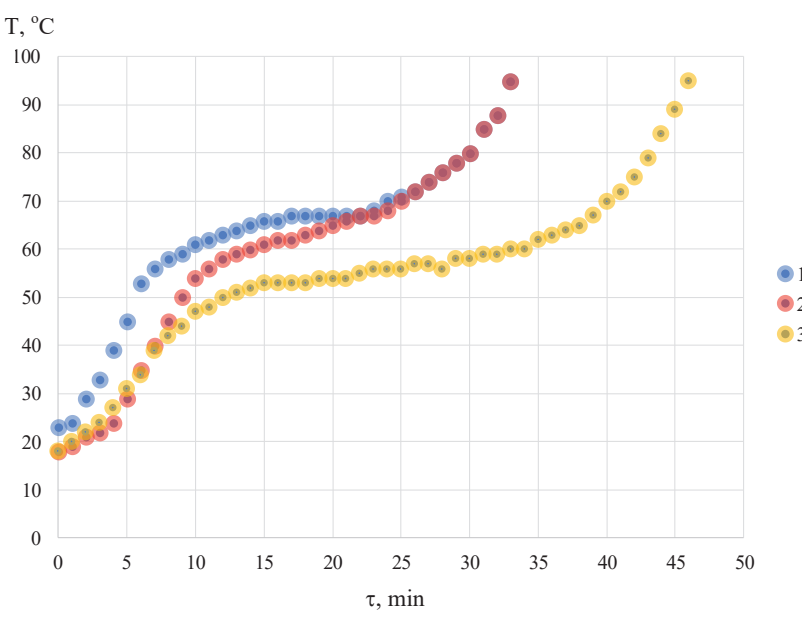

Fig. 8. Thermograms of the drying process at a distance to the emitters: $1-7 \mathrm{~cm} ; 2-10 \mathrm{~cm} ; 3-13 \mathrm{~cm}$

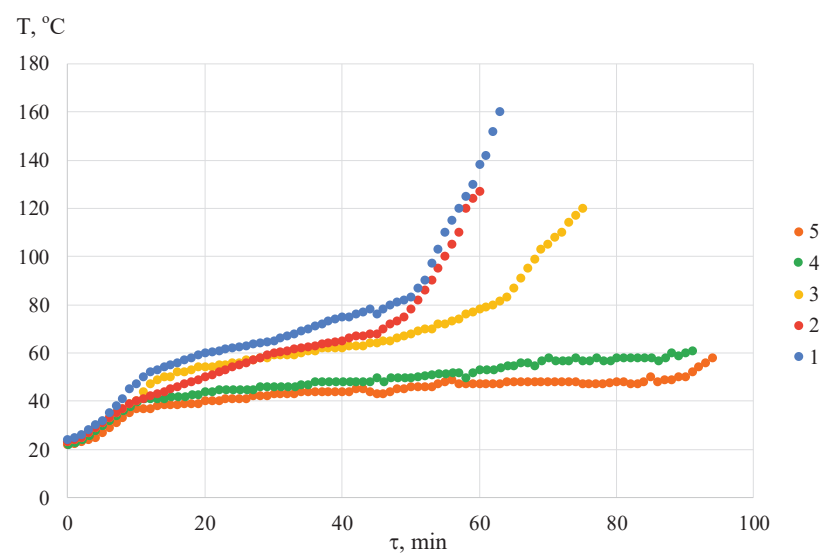

Fig. 9. Thermograms of the drying process: $1-0 \mathrm{~m} / \mathrm{s} ; 2-0.5 \mathrm{~m} / \mathrm{s} ; 3-1 \mathrm{~m} / \mathrm{s} ; 4-2 \mathrm{~m} / \mathrm{s} ; 5-2.5 \mathrm{~m} / \mathrm{s}$

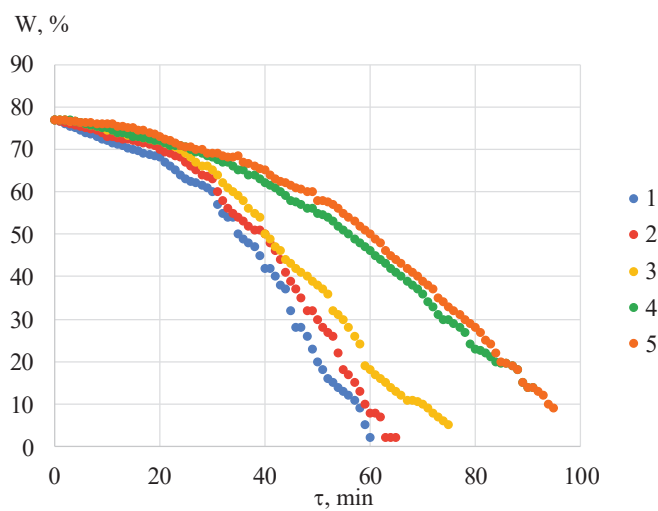

Fig. 10. Lines of change in humidity at air speed in the chamber: $1-0 \mathrm{~m} / \mathrm{s} ; 2-0.5 \mathrm{~m} / \mathrm{s} ; 3-1 \mathrm{~m} / \mathrm{s} ; 4-2 \mathrm{~m} / \mathrm{s} ; 5-2.5 \mathrm{~m} / \mathrm{s}$

At air speeds greater than $0.5 \mathrm{~m} / \mathrm{s}$, a decrease in the drying speed is observed (Fig. 11), since the moisture content of the diffusion medium above the product increases and the driving force of the process decreases.

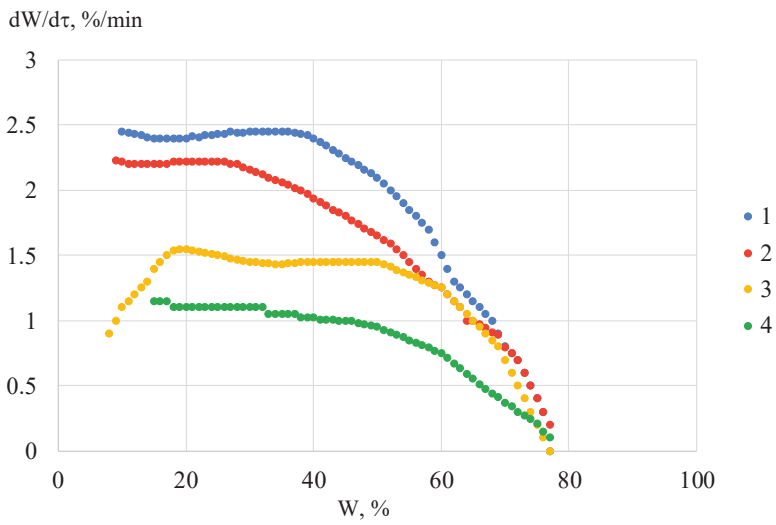

Fig. 11. Lines of speed of the drying process at the air speed in the chamber: $1-0 \mathrm{~m} / \mathrm{s} ; 2-0.5 \mathrm{~m} / \mathrm{s} ; 3-1 \mathrm{~m} / \mathrm{s} ; 4-2 \mathrm{~m} / \mathrm{s}$

Thus, it is recommended that air flow rates in the drying chamber be maintained at a level that corresponds to $0.5 \mathrm{~m} / \mathrm{s}$.

6.2. Kinetics studies of infrared drying of spent coffee grounds in a moving layer. A series of experiments on this problem are carried out at the stand (Fig. 3). The direction of research is to establish the influence of factors characteristic of the mobile layer on the dehydration effectiveness.

The influence of power on the average speed of the drying process is determined. The experiments are carried out at a conveyor tape speed of $0.13 \mathrm{~cm} / \mathrm{s}$, specific load $3 \mathrm{~kg} / \mathrm{m}^{2}$. One IR module is functioned. The amount of moisture removed is determined by the initial and final moisture content of the grounds according to the method of drying to constant weight. The drying rate is calculated by the amount of removed moisture and the time during which the IR radiation acted on the grounds (Fig. 12).

With an increase in the amount of energy input by a factor of three, the rate of moisture removal increases by $30 \%$ (Fig. 12). The average drying rate is $1.3-1.7 \% / \mathrm{min}$.

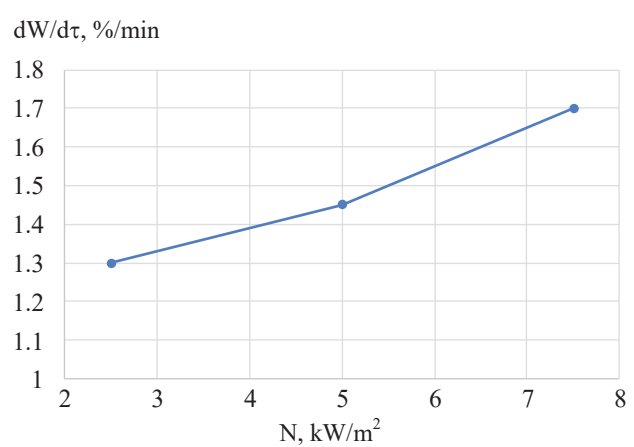

Fig. 12. The influence of the specific power of infrared radiation on the drying rate of spent coffee grounds

The influence of the tape speed on the IR drying intensity is determined. The speed of the tape is associated with the length of time when the grounds are exposed to IR radiation. The experiments are carried out with a specific load of $2.5 \mathrm{~kg} / \mathrm{m}^{2}$, the specific power of one working IR module is $5 \mathrm{~kW} / \mathrm{m}^{2}$ (Fig. 13).

At minimum speed, the product heats up more intensely, thermal damage to the upper layer due to prolonged exposure to infrared radiation is not observed. The plant 
productivity in the loading mode of $3 \mathrm{~kg} / \mathrm{m}^{2}$ at a speed of $0.33 \mathrm{~cm} / \mathrm{s}$ is $1.5 \mathrm{~kg} / \mathrm{h}$ of dry grounds with a humidity of $10 \%$.

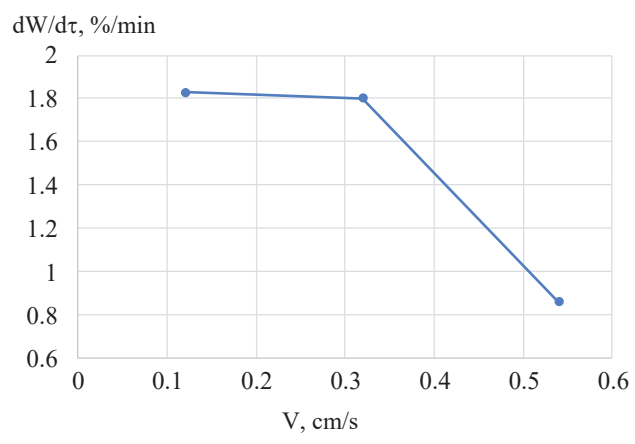

Fig. 13. Effect of tape speed on moisture removal rate

The influence of the number of infrared modules is determined. An increase in the number of IR modules leads to an increase in the length of time the product stays under the influence of radiation. This allows to use higher product speeds and increase plant productivity. The speed of the conveyor tape is $0.33 \mathrm{~cm} / \mathrm{s}$, the product load is $2.5 \mathrm{~kg} / \mathrm{m}^{2}$, and the supplied specific power is maintained at $5 \mathrm{~kW} / \mathrm{m}^{2}$ (Fig. 14).

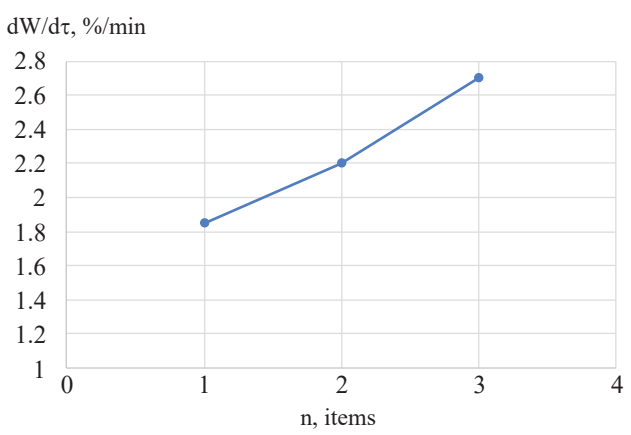

Fig. 14. The effect of the number of infrared modules on the rate of moisture removal

With an increase in the number of modules from 1 to 3 , the drying rate increases by 1.5 times (Fig. 14).

The influence of specific load is determined. The specific load is determined by the thickness of the product layer. The experiments are carried out at a specific load of $1.2-3.3 \mathrm{~kg} / \mathrm{m}^{2}$, a product speed of $0.13 \mathrm{~cm} / \mathrm{s}$, and a supply of $5 \mathrm{~kW} / \mathrm{m}^{2}$ of energy from IR generators (Fig. 15).

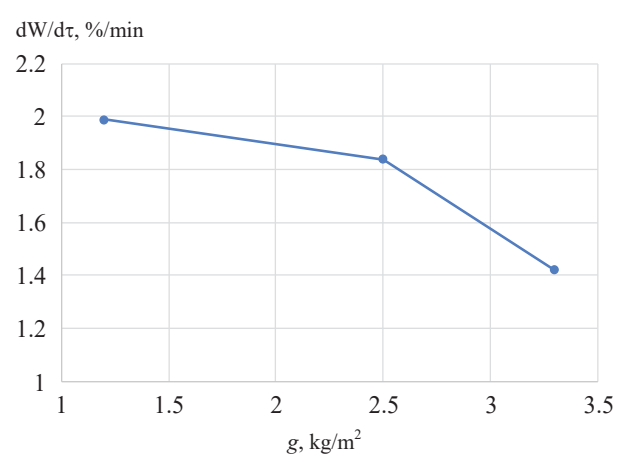

Fig. 15. The influence of specific load on the rate of moisture removal
A sharp decrease in the rate of moisture removal at a load greater than $2.5 \mathrm{~kg} / \mathrm{m}^{2}$ confirms that infrared radiation penetrates the product to a certain depth. With a larger layer thickness, energy does not act on the entire mass of the product on the tape, which leads to a decrease in the intensity of the drying process, and the upper layers of the product create resistance to moisture transfer from the lower layers to the diffusion medium.

\section{SWOT analysis of research results}

Strengths. The studied drying method has low energy consumption $(3.2 \mathrm{MJ} / \mathrm{kg})$ compared with convective dryers (5-9 MJ $/ \mathrm{kg})$. The use of infrared drying will save valuable polyphenols in spent coffee grounds, stabilize it without affecting the bioactive properties. The use of a tape IR dryer will increase productivity, implement the process on an industrial scale.

Weaknesses. It is difficult to compete in performance with convection dryers.

Opportunities. By introducing an IR dryer for spent coffee grounds, the company will receive a new energyefficient technology for processing waste. This will reduce the load on the lithosphere.

Threats. Specific equipment is required to implement the process of IR drying.

\section{Conclusions}

1. The influence of regime parameters (intensity of energy supply, temperature, air flow rate, product layer thickness and specific load) on the kinetics of periodic IR drying of spent coffee grounds is determined. An increase in the power supplied to the product by 4 times reduces the drying time by 2.5 times (Fig. 5). A decrease in the thickness of the grounds layer by a factor of 2 leads to an increase in the drying rate by a factor of $2-3$. An increase in the thickness of the layer also leads to uneven heating and drying of the product. While the temperature in the thickness of the grounds does not exceed $70{ }^{\circ} \mathrm{C}$, the surface heats up to $150{ }^{\circ} \mathrm{C}$ and above. Changing the distance of the product from the emitter within the studied limits does not significantly affect the rate of moisture removal from the grounds (Fig. 8). With increasing air speed in the chamber, the temperature of the product decreases (Fig. 10), which indicates an increase in energy loss with exhaust air. At air speeds greater than $0.5 \mathrm{~m} / \mathrm{s}$, a decrease in the drying rate is observed (Fig. 11).

2. The influence of regime parameters (intensity of energy supply, specific load, tape speed, number of IR modules) on the kinetics of continuous IR drying of spent coffee grounds is determined. At minimum speed, the product heats up more intensely, thermal damage to the upper layer due to prolonged exposure to infrared radiation is not observed. With an increase in the number of modules from 1 to 3 , the drying rate increased by 1.5 times (Fig. 14). A sharp decrease in the rate of moisture removal at a load greater than $2.5 \mathrm{~kg} / \mathrm{m}^{2}$ confirms that infrared radiation penetrates the product to a certain depth.

\section{References}

1. Burdo, O. G. (2010). Evoliuciia sushilnykh ustanovok. Odessa: Poligraf, 368

2. Rudobashta, S. P. (1980). Massoperenos v sistemakh s tverdoi fazoi. Moscow: Khimiia, 248. 
3. Krishnamurthy, K., Khurana, H. K., Soojin, J., Irudayaraj, J., Demirci, A. (2008). Infrared Heating in Food Processing: An Overview. Comprehensive Reviews in Food Science and Food Safety, 7 (1), 2-13. doi: http://doi.org/10.1111/j.1541-4337.2007.00024.x

4. Sandu, C. (1986). Infrared Radiative Drying in Food Engineering: A Process Analysis. Biotechnology Progress, 2 (3), 109-119. doi: http://doi.org/10.1002/btpr.5420020305

5. Atabani, A. E., Al-Muhtaseb, A. H., Kumar, G., Saratale, G. D. Aslam, M., Khan, H. A. et. al. (2019). Valorization of spent coffee grounds into biofuels and value-added products: Pathway towards integrated bio-refinery. Fuel, 254, 115640. doi: http:// doi.org/10.1016/j.fuel.2019.115640

6. Sabarez, H. (2016). Drying of Food Materials. Amsterdam: Elsevier. doi: http://doi.org/10.1016/b978-0-08-100596-5.03416-8

7. Onwude, D. I., Hashim, N., Janius, R. B., Nawi, N. M., Abdan, K. (2016). Modeling the Thin-Layer Drying of Fruits and Vegetables: A Review. Comprehensive Revieres in Food Science and Food Safety, 15 (3), 599-618. doi: http://doi.org/10.1111/1541-4337.12196

8. Saavedra, J., Córdova, A., Navarro, R., Díaz-Calderón, P., Fuentealba, C., Astudillo-Castro, C. et. al. (2017). Industrial avocado waste: Functional compounds preservation by convective drying process. Journal of Food Engineering, 198, 81-90. doi: http:// doi.org/10.1016/j.jfoodeng.2016.11.018

9. Gómez-de la Cruz, F. J., Cruz-Peragón, F., Casanova-Peláez, P. J. Palomar-Carnicero, J. M. (2015). A vital stage in the large-scale production of biofuels from spent coffee grounds: The drying kinetics. Fuel Processing Technology, 130, 188-196. doi: http:/ doi.org/10.1016/j.fuproc.2014.10.012

10. Potapov, V. A. (2015) Filtracionnaia sushka pri povyshennom davlenii. Naukovi praci ONAKHT, 47 (2).

11. Burdo, O., Bezbakh, I., Kepin, N., Zykov, A., Yarovyi, I., Gavrilov, A. et. al. (2019). Studying the operation of innovative equipment for thermomechanical treatment and dehydration of food raw materials. Eastern-European Journal of Enterprise Technologies, 5 (11 (101)), 24-32. doi: http://doi.org/10.15587 1729-4061.2019.178937

12. Prommuak, C., Tharangkool, N., Pavasant, P., Ponpesh, P., Jarunglumlert, T. (2020). Computational fluid dynamic design of spent coffee ground cabinet dryer using recycled heat from air compressor. Chemical Engineering Research and Design, 153, 75-84. doi: http://doi.org/10.1016/j.cherd.2019.10.017

13. Burdo, O. G., Terziev, S. G., Ruzhickaia, N. V., Makievskaia, T. L. (2014). Processy pererabotki kofeinogo shlama. Kyiv: EnterPrint, 228.

14. Fu, B. A., Chen, M. Q. (2019). Microwave drying performance of spent coffee grounds briquette coupled with mineral additives. Drying Technology, 1-8. doi: http://doi.org/10.1080/07373937. 2019.1692862

15. Osorio-Arias, J., Delgado-Arias, S., Cano, L., Zapata, S., Quin tero, M., Nuñez, H. et. al. (2019). Sustainable Management and Valorization of Spent Coffee Grounds Through the Optimization of Thin Layer Hot Air-Drying Process. Waste and Biomass Valorization. doi: http://doi.org/10.1007/s12649-019-00793-9
16. Chen, N. N., Chen, M. Q., Fu, B. A., Song, J. J. (2017). Far-infrared irradiation drying behavior of typical biomass briquettes. Energy, 121, 726-738. doi: http://doi.org/10.1016/ j.energy.2017.01.054

Burdo Oleg, Doctor of Technical Sciences, Professor, Department of Processes, Equipment and Energy Management, Odessa National Academy of Food Technologies, Ukraine, e-mail: burdo.onaft@gmail.com, ORCID: http://orcid.org/0000-0002-2630-1819

Bezbakh Igor, Doctor of Technical Sciences, Associate Professor, Department of Processes, Equipment and Energy Management, Odessa National Academy of Food Technologies Ukraine, e-mail: igorbezbakh1003@gmail.com, ORCID: http://orcid.org/0000-00022353-1811

Shyshov Serhii, Postgraduate Student, Department of Processes, Equipment and Energy Management, Odessa National Academy of Food Technologies, Ukraine, e-mail: try2stopmeme@gmail.com, ORCID: https://orcid.org/0000-0001-8891-025X

Zykov Aleksandr, Doctor of Technical Sciences, Department of Processes, Equipment and Energy Management, Odessa National Academy of Food Technologies, Ukraine, e-mail: zav380@yahoo.com, ORCID: http://orcid.org/0000-0001-8345-1015

Gavrilov Aleksander, PhD, Associate Professor, Department of Technology and Equipment Production and Processing of Livestock Products, Academy of Bioresources and Environmental Management «V. I. Vernadsky Crimean Federal University», Simferopol, Republic of Crimea, e-mail: tehfac@mail.ru, ORCID: http://orcid.org/ 0000-0003-3382-0307

Vsevolodov Oleksandr, PhD, Associate Professor, Department of Processes, Equipment and Energy Management, Odessa National Academy of Food Technologies, Ukraine, ORCID: https://orcid.org/ 0000-0002-5157-5977

Sirotyuk Ilya, Assistant, Department of Processes, Equipment and Energy Management, Odessa National Academy of Food Technologies, Ukraine, e-mail:ilyxin09@gmail.com, ORCID: http://orcid.org/ 0000-0002-2081-0954

Terziev Sergey, Doctor of Technical Sciences, Head of Board Public Joint Stock Company «Enni Foods», Odessa, Ukraine, e-mail:poem.onaft@gmail.com,ORCID: http://orcid.org/0000-00020460-4288 